Mr. sc. Almir Pustahija ${ }^{1}$

\title{
GENERIRANJE SUVREMENOG TERORIZMA KROZ PRIZMU NEGATIVNIH KONOTACIJA GLOBALIZACIJE - PRIMJER BIH
}

\author{
UDK: 327.343 (497.6) \\ Stručni rad \\ Primljeno: 1. 6. 2016.
}

\begin{abstract}
Autor u radu analizira suvremeni terorizam, posebno naglašavajući dubinske dimenzije uzrokovanja, rađanja, proizvodnje suvremenog terorizma, istovremeno se osvrćući kritički na negativne konotacije globalizacije, odnosno na globalne procese u svijetu i ključne faktore koji uveliko doprinose stvaranju nesigurnosti s pratećim posljedicama. Pristup koji je u radu primijenjen može objasniti rađajuću suštinu suvremenog terorizma, da bi se društvo kao takvo oslobodilo okova uvriježenosti u vidu apsorpcije dolazećih necjelovitih i spinovanih informacija, proizvodeći strah od terorističkih aktivnosti.

Također, u radu su sa kazneno-procesnog i sigurnosnog aspekta analizirani teroristički akti koji su se desili u Bosni i Hercegovini od njezine samostalnosti do danas, ukazujući istovremeno na mogućnost produbljivanja te vrste nesigurnosti, odnosno fenomena suvremenog terorizma koji se reflektira na posebne načine u društvu, ali i na specifičnosti ukupnog sektora sigurnosti Bosne i Hercegovine i njegove borbe u prevenciji i suzbijanju unutarnjeg, međudržavnog, kao i transnacionalnog terorizma. Zaključak u radu referira na činjenicu da pored državnih institucija koje su involvirane $u$ aktivnostima suzbijanja i borbe protiv terorizma, postoje i druge instance koje su se aktivnije uključile u spomenutom djelovanju, kao što su vjerske institucije/zajednice u Bosni i Hercegovini.
\end{abstract}

Ključne riječi: suvremeni terorizam, uzrokovanje, globalizacija, kaznenoprocesni aspekt

\section{UVOD}

Kao uvod u problematiku rada osvrnut ćemo se načinjenicu što u stvari predstavlja suvremeni terorizam. S obzirom na moguće učinke, suvremeni terorizam je postao globalna opasnost i jedan od najvećih svjetskih problema. Jedan je od najozbiljnijih i najopasnijih problema suvremenog svijeta i za njega ne postoje granice jer je vrlo prilagodljiv i u praksi teško predvidiv. U radu bavit ćemo se pitanjima koja

1 Mr. sci. Almir Pustahija, doktorand i stručni suradnik na nastavnom predmetu Sistemi privatne sigurnosti na Fakultetu za kriminalistiku, kriminologiju i sigurnosne studije u Sarajevu (BiH). Autor u tekstu iznosi osobna stajališta.E mail: apustahija-ds@fkn.unsa.ba 
se odnose na generiranje ${ }^{2}$ suvremenog terorizma i oblika njegova djelovanja kao prvog ključnog faktora kroz utjecaj neoliberalne i imperijalističke svjetske politike s kolonijalnim pretenzijama i ambicijama na ostatak svijeta. Trenutna i ne tako nezabrinjavajuća sigurnosna situacija u svijetu, kroz načine plasiranja konstruiranih ili cenzuriranih medijskih izvješća zapravo nas udaljava od ključnog problema, a to su: uzroci, proizvodnja, rađanje suvremenog terorizma. Mišljenja smo da je permanentno ukazivanje na stvarne uzroke, rađanje suvremenog terorizma, jedini ispravni put, pravac otkrivanja i spoznaje što su i čiji su motivi za proizvodnju ovog fenomena, koji, kako smo i spomenuli, predstavlja jedan od najvećih sigurnosnih problema današnjice, da bismo mogli u konačnici kao globalno društvo djelotvornim korektivima odlučno i pravovremeno intervenirati i suprotstaviti se ovom negativnom procesu.

Provođenje terorističkih akata, služeći se na sistematski način općeopasnim radnjama i aktima nasilja, stremi tome da izazove strah, užas, nemir i nespokojstvo kod stanovništva da bi se time dosegli određeni ciljevi, naročito političke i ideološke prirode. Terorizam je kao takav u svom pojavnom obliku i u pežorativnom kontekstu teško odrediti, a u konačnici i definirati. ${ }^{3}$ U tom kontekstu, Cooper (2001:881-893) na jednostavan način ističe da je „problem u definiciji problema“, smatrajući kako se možemo složiti da je terorizam problem, ali i da se generalno ne možemo složiti oko toga što je problem terorizma kroz njegovo definiranje. Terorizam je u pedeset godina hladnoga rata uglavnom bio predvidiv i racionalan, predstavljao je igru prema jasno utvrđenim pravilima. Nekada je to bio instrument praktične diplomacije, i prije je ovisio o dogovoru nego o određenom sukobu, odnosno ratu, što sa današnjeg suvremenog stajališta to nije slučaj. U modernom dobu u kojem živimo sve više smo mišljenja da je terorizam postao jedan od oblika borbe protiv novih kolonizatora, promatrajući globalizacijske procese uz njihove negativne utjecaje koji su u konačnici doveli do dramatičnog porasta ekonomskih i društvenih nejednakosti na međunarodnom nivou. Suvremeni terorizam obuhvaća široki dijapazon destruktivno razornih akcija, ali i raznovrsnih neprijatelja, kako na globalnom, tako i na lokalnom planu. Današnji terorizam je postao izuzetno brutalan, nasilan, razularen, iracionalan, patološki destruktivan, jer dobiva značajnije razmjere i postaje izuzetno ozbiljan sigurnosni problem kako za običnu

2 Pojam potječe od latinske riječi generare, što predstavlja rađanje. Također, pojam se dalje proširuje u stvaranje, proizvodnju, uzrokovanje - Vujaklija, M. (1980.), Leksikon stranih reči i izraza, Prosveta, Beograd.

Terorizam je namjerno i sistemsko ubijanje, sakaćenje i ugrožavanje nevinih kako bi se u njih utjerao strah radi neke političke svrhe. Terorizam je u vezi s moći. (Vidi u: Harmon, Christofer C., „Terorizam danas“, GM Zagreb, 2002:13-19); Terorizam se može najopćenitije odrediti kao složen oblik organiziranog, individualnog i rjeđe institucionalnog političkog nasilja, obilježenog zastrašujućim brahijahalno-fizičkim i psihološkim metodama političke borbe. (Vidi u: Simeunović, Dragan, „Međunarodni terorizam“, Beogradski forum za svet ravnopravnih, Beograd, 2002:13). 
populaciju građana, tako i za cjelokupne nacionalne sigurnosti, što i dokazuju zbivanja diljem svijeta. Jednostavnije rečeno, suvremeni se terorizam izvrsno prilagodio modernizaciji globalnog društva, razvio svoje korijene i postao jedna od najvećih sigurnosnih prijetnji svjetskom poretku.

\section{KOMPLEKSNOST PROBLEMATIKE SUVREMENOG TERORIZMA I NEGATIVNIH KONOTACIJA GLOBALIZACIJE}

Suvremeni terorizam današnjice evoluirao je organizacijski i u svojim drugim aspektima. Kompleksnost suvremenog terorizma ogleda se u njegovim različitim oblicima i načinima djelovanja, kao i u akterima u procesu planiranja, pripremanja i izvršenja terorističkih akata. Prema autorima Orehovec, Stipetić (2011.), „terorizam je metoda ponavljanja nasilnog djelovanja koja uzrokuje zabrinutost i strah upotrebljene od strane tajnih pojedinaca, skupina ili državnih učesnika, iz idiosinkratskih, kaznenih ili političkih razloga, koje za razlikuju od atentata izravne mete nasilja nisu glavne mete... ljudske mete nasilja obično su izabrane nasumično ili selektivno iz ciljane populacije..."

Kao što je uočio Gaćinović (2010.), ,izučavanje problematike suvremenog terorizma je posao pun neizvjesnosti i naučnog rizika“. Proširujući to mišljenje, izučavanje istovremeno može biti izazov za ljude koji se bave ovom vrstom znanstvenog ali i stručnog djelovanja, kao i izuzetna odgovornost, jer znanstvena i stručna javnost i društvo uopće opravdano očekuju nove znanstvene iskorake i njihovu primjenu u prevenciji i borbi protiv suvremenog terorizma.

Gledajući u tom pravcu, autor za potrebe rada daje definiciju suvremenog terorizma koja na prvi pogled ima komprimirajući izgled, ali suštinski i sadržajno, opravdano zbog ranijih mnogobrojnih koje su opširno obuhvaćale pojmove i važne aspekte unutar njih. Na ovaj način pokušalo se precizirati uže, jasno, ali i adekvatno značenje svih složenih pojava koje obuhvaćaju ovaj prije svega specifični sigurnosni problem, a zatim znanstveni i stručni izazov modernog vremena. Suvremeni terorizam je izraz krize u svakom mogućem smislu i na toj razini:

Suvremeni terorizam može se odrediti kao složeni oblik organiziranog, individualnog, institucionalnog političkog $i$ nasilnog djelovanja s obilježjima brutalnosti, razularenosti, iracionalizma i patološke destruktivnosti, istovremeno primjenjujući psihološke metode, po pravilu usmjerene prema ciljevima političke borbe kojima se obično u vrijeme političkih i ekonomskih kriza, a rjeđe u uvjetima ekonomske i političke stabilnosti jednog društva, sistematski pokušavaju ostvariti zadani ciljevi, na način potpuno neprimjeren datim uvjetima, uzrokujući time destabilizaciju, nesigurnost $i$ žrtve. 
Bavljenje pitanjem suvremenog terorizma i njegovim generiranjem iz kuta nestandardiziranog pogleda zapadnjaka, odnosno kuta koji se ne promatra, percipira uhodanim, u mnogome uvriježenim sistemom razmišljanja, ciljanom političko-sigurnosnom logikom i filozofijom, jest epicentar problema, istovremeno bitno različit od spomenutog, uobičajenog. Za dio populacije koja promišlja suprotno, o istoj problematici (suvremenog terorizma) moglo bi se reći da ima unaprijed formirane stavove pod svakodnevnim utjecajem zapadnih masmedija potpomognutih i višim državnim instancama, o čemu se prvenstveno ne ispituju najbitniji elementi globalnog sigurnosnog problema suvremenog terorizma, odnosno njegovi jedinstveni uzroci, motivi, razlozi rađanja, već se sve podrazumijeva na zadanoj matrici i po istim načelima.

Pretpostavljajući da je terorizam postao sigurnosnim globalnim fenomenom, isti se počinje istovremeno uspoređivati sa svojevrsnom reakcijom na globalne procese, odnosno s negativnom posljedicom širenja ekonomskih, političkih, ali i ostalih dostignuća razvijenih sila.

U tom kontekstu Bžežinski (2001.) govori o američkom primatu u svijetu s geopolitičkim ciljevima, gdje objašnjava kako i na koji način se destabiliziraju zemlje iznutra, da bi se srušile, odnosno da bi se uveli novi njima lojalni politički sistemi.

Suvremene terorističke skupine, bez točno određenog matičnog teritorija sjajno su se prilagodile modernom svijetu, a olakotnu okolnost predstavlja im i nesmetana komunikacija širom planeta.

Bušljeta-Tonković (2014.) smatra da razvijene zemlje terorizam najčešće sagledavaju sa svojevrsnoga etnocentričnog stajališta, kao i da terorističke prijetnje i napadi, u ogromnoj mjeri, služe ostvarenju veće kontrole modernih država Zapada nad gotovo cijelim svijetom, posebno onim dijelovima planeta u kojima se kriju velika prirodna bogatstva i resursi. ${ }^{4}$

Karakteristično je to da se svuda gdje su zapadne sile intervenirale $i$ uvodile poredak zametnuo pokret otpora u nekim vidovima terorizma. To je ono što zapadne vlade i njihova administracija generalno žele prikriti, blaže rečeno minimiziraju, istovremeno ne pružajući takve informacije javnosti koje bi trebale dati bitne odgovore na probleme proizvodnje i uzroka suvremenog terorizma, za koje ogroman broj populacije nije u prilici ni saznati.

Kao što je uočio Ranković (2005.), korijeni suvremenog terorizma zapravo leže u politici ekspanzije s osloncem na vojni intervencionizam i hegemonizam, danas naročito prema muslimanskim zemljama. Naravno da nisu u pitanju čisto vjerski

4 Bušljeta-Tonković, A. (2014.), „Suvremeni terorizam - globalna sigurnosna prijetnja i/ili oblik antiglobalizacijskoga djelovanja“, pregledni članak, Mostariensia, 18, 1-2, str. 277-292. 
motivi i antagonizmi, već ekonomski, prvenstveno kontrola nad izvorima energije, odnosno, kako J. Stiglitz ističe, ,prokletstvo prirodnih resursa“ (Stiglitz, 2009:62).

S druge strane, imamo shvaćanje suvremenog terorizma kao oblika globalne sigurnosne prijetnje kroz odraz globalizacijskih procesa, koji se istovremeno ne ostvaruje za opće dobro.

U izvedenom kontekstu Baudrillard (2007:61) smatra da „današnji terorizam nije produkt tradicionalne historije anarhizma, nihilizma ili fanatizma, to je suvremeni partner globalizacije“.

Pojam globalizacije može se shvatiti i definirati na različite, ponekad i kontradiktorne načine. U tom kontekstu, Hobsbaum (2008.) ističe da je globalizacija proces težnje ka svijetu kao jedinstvenom elementu međusobno povezanih aktivnosti koje nisu sputane lokalnim granicama.

Prema riječima Becka (2003.), globalizacija je proces gospodarskog, socijalnog, kulturnog i političkog djelovanja koje nadmašuje granice nacionalnih država, dok Turek (1999.) ističe da bi globalizacija podrazumijevala socijalni proces koji teži sveobuhvatnosti i jedinstvenosti svijeta.

Općenito, globalizaciju bismo mogli promatrati kao proces gospodarskog, političkog, socijalnog i kulturnog djelovanja na nadnacionalnom nivou, proces koji na globalnoj razini mijenja ustaljene političke, gospodarske, socijalne i kulturne odnose.

To praktično znači da globalizacija nije samostalan proces, ona podrazumijeva niz procesa koji djeluju istodobno i neravnopravno na više razina kao i različitih dimenzija. Globalizacija je ujedno proces koji uključuje i oblikuje unutarnju i vanjsku politiku svake države, određuje uvjete ekonomskih i financijskih aktera. Uz promjene koje globalizacija donosi, dolaze i određene negativne posljedice, osobito nejednakosti između tzv. Prvoga i Trećega svijeta.

Pod okriljem globalizacije razvijene zemlje ostvaruju ekonomski profit (primarni interes), povlastice, vodstvo, nadzor, utjecaj, moć i one su potpuno dominantne na svjetskoj razini.

Tako su npr. Sjedinjene Američke Države, ne čekajući rezoluciju UN-a, uz pomoć Velike Britanije napale Irak, pravdajući napade postojanjem oružja za masovno uništenje, ali na kraju ništa od tog oružja nije pronađeno. Ta zemlja je temeljito opljačkana, popaljena i u potpunom rasulu, a naftna polja i dalje uredno rade pod stopostotnom kontrolom transnacionalnih korporacija sa sjedištem $\mathrm{u}$ SAD-u (Kalinić, 2003: 44).

Umjesto integracije svijeta, događa se njegova fragmentacija, a produbljivanje nejednakosti snažan je poticaj religijskom fundamentalizmu i agresivnom 
nacionalizmu koji svijet dijeli na različite civilizacije. Kako ističe Pratt, 2006: 57, religijski fundamentalizam odnosi se na tip stavova koji se može pronaći u raznim svjetskim religijama. Specifično, on se može odnositi na porast svijesti sa relativno bezopasnog, zastarjelog, ultra-religijskog sistema vjerovanja do spremnosti da se agresivno nameće drugima.

Također, utjecaj transnacionalnih korporacija na nacionalne vlade postaje sve jači, nezaposlenost i neimaština u zemljama u razvoju je sve veća, a posljednjih godina prouzročenom svjetskom ekonomskom krizom na udaru su i građani u bogatim zemljama, kroz prizmu nižeg životnog standarda i gubitka zaposlenja.

Mandelbaum (2006.) ističe da protivnici globalizacije istu povezuju $\mathrm{s}$ imperijalizmom, ili, iz kuta sadašnjosti, s neoimperijalizmom, koji se ujedno najviše pripisuje najvećoj svjetskoj sili današnjice. „Imperijalizam kao riječ i pojava je demonizovanog karaktera jer ukazuje na podređivanje, prinudu i nejednakost“".

Globalizaciju ne možemo isključivo promatrati kao jednosmjernu ulicu kojom gospodare zapadne sile, jer u određenoj mjeri pojedine zemlje Istoka nameću vlastite principe kao što su religije, migracije i dr.

Kako ističe Đorić (2011.), uslijed tih pomjeranja stanovništva, pridošlice u određenim slučajevima narušavaju homogenu kulturološko-nacionalnu strukturu i disperziraju sistem vrijednosti u sve zemlje gdje dođu. ${ }^{5}$

Primjetno je da pod udarima globalizacije sve može pasti osim ideologije nacionalizma i iz tog razloga stremljenja globalizacijskih procesa, točnije globalnih aktera, da minimiziraju takvo djelovanje nacionalnih ideologija u bilo kojem obliku (negativnom i pozitivnom) zapravo samo sve više učvršćuju njihovu poziciju, stvarajući otpor i jačanje takvih struktura u njihovim društvima. Osim izdvojenog nacionalnog, globalizacijski procesi, akteri, imaju is druge strane protivnike u vidu anarhista i pripadnika većine ekoloških pokreta i dr. I pored tog neskrivenog otpora, možda će u budućnosti nacionalno kao takvo moći biti zajedno s globalnim, ili će pak drugo uspjeti minimizirati ili uništiti prvo, kako kaže M. B. Steger (2005:133), zbog ,ugnjetavačke strukture globalnog aparthejda“. To ostaje da se vidi.

QVraćajući se unatrag na problem suvremenog terorizma i njegova uzrokovanja, a prema riječima Dizdarevića (2015.), zapadnjačka proizvodnja i očuvanje sociopatoloških komponenti koje su saveznik tih istih struktura, služe za destabilizaciju i rekompoziciju geostrateškog prostora, u njihovom pohodu ka, moglo bi se reći, fašistoidnom korporativnom imperijalizmu. ${ }^{6}$ Osim toga, ne

5 Đorić, M. (2011.), „Globalizacija i politički ekstremizam, II deo: Međunarodna politika $i$ međunarodni odnosi, Godišnjak broj 5, lipanj 2011: 417-418, Fakultet političkih nauka, Beograd.

6 FALIŠ - Festival ljevice $i$ alternative Šibenik (2015.). Pristupljeno 26. studenoga 2015.: http://kontrapress.com/clanak.php?rub=Politika\&url=Idemo-u-susret-fasisoidnom-korporativnomimperijalizmu 
smijemo zanemariti bitnu činjenicu financiranja spomenutih komponenti od strane zapadnih saveznika, ${ }^{7}$ koji to obavljaju na manje konspirativan i nadasve njima svrsishodan način. U prilog tome govori činjenica da trenutno imamo na stotine tisuća ljudi koji se mogu regrutirati za vrlo kratko vrijeme, posebno uključujući metodu prozelitizma, slijedeći ideje radikalizma svake vrste, pod prezentiranim im izgovorom o odsutnosti ljudskih prava i sloboda, o ispravljanju nepravde, demokratičnosti i boljem životu u svojim zemljama. Gledajući u tom pravcu, Azinović, Jusić (2015.) ističu, kada je riječ o bosanskohercegovačkim prilikama, da je najjači val odlazaka građana Bosne i Hercegovine na strana ratišta (Sirija i Irak) najvjerojatnije prošao, a za pretpostaviti je da cee se trend ideološke radikalizacije, vrbovanja i poticanja na nove odlaske nastaviti.

\section{UTJECAJI POLITIKE SVJETSKIH SILA NA MEĐUNARODNE ODNOSNE I (NE)SIGURNOST}

Sjedinjene Američke Države, koje predstavljaju najveću svjetsku silu moderne povijesti, otpočele su svoj imperijalistički pohod još 1899. godine okupacijom Filipina, a i danas, nakon jednog stoljeća, primjećujemo da se takva politika nije mnogo promijenila u svojoj suštini. Danas, gledajući s aspekta proizvodnje oružja, Sjedinjene Američke Države ulažu više nego ostale svjetske sile zajedno (Francuska, Velika Britanija, Njemačka, Japan, Kina i dr.) i moglo bi se reći da nema ni pomisli o smanjivanju tog procesa niti zaustavljanju dominacije na svjetskoj vanjskopolitičkoj sceni, provodeći zadatke svjetskog policajca, u ime zaštite ljudskih prava, sloboda i dobrobiti čovječanstva.

Kada bi djelovanje u tom pravcu bilo s iskrenim namjerama, iz humanitarnog ugla i s aspekta empatije prema stanovništvu na ratom ugroženim područjima, većina svjetske javnosti sasvim sigurno dala bi podršku za realizaciju tih aktivnosti, međutim prije svega izvještaji bivših i sadašnjih djelatnika američke administracije i državnih službi, kao i mnogi znanstveni i stručni radovi, ukazuju upravo na suprotno, odnosno na umiješanost spomenute strane iz interesne sfere, u konačnici koristoljublja.

Na početku se pokušava u najmanjoj mogućoj mjeri koristiti vojna sila, pod prethodno navedenim izgovorima, dok hegemonizam kao izraz dominacije i prevlasti za posljedicu ima iskorištavanje prirodnih i drugih resursa pojedinih zemalja, a u završnoj fazi i nametanje kulturoloških i tehnoloških interesa.

7 Više u: Džamić, D. (2004.), Cia iznutra, Knjiga komerc, Beograd, 2004:28-29. 
Mr. sc. Almir Pustahija: Generiranje suvremenog terorizma kroz prizmu negativnih konotacija... Zbornik radova Pravnog fakulteta u Splitu, god. 53, 4/2016., str. 1095.-1118.

Opširnije i retroaktivno promatrajući zapadne sile, i njihovi saveznici vode ratove protiv skupina i zemalja koje se opiru njihovoj hegemoniji. Odnosno, drugačije rečeno, na jednoj stani imamo građansku liberalnu demokraciju, slobodno tržište i kapitalizam, a na drugoj zemlje sa svojim državnim ustrojstvom koje žele napredovati u skladu sa svojom filozofijom i sistemom vrijednosti. Dio tih ratova vodi se od strane zapadne ekspanzionističke, licemjerne politike i izvršilaca zamišljenih intervencija, kada se oružjem nameće svoj sistem vrijednosti svima onima koji zbog drugačije tradicije, kulture i historijskog nasljeđa ne žele biti njegov dio.

Pojedinci koji se nalaze u službama određenih interesnih skupina: politički i sigurnosni eksperti, analitičari, kao i novinari kroz analize, napise u masmedijima kao „faktorima dinamike $i$ tranzicije društvenih odnosa, ali $i$ pokretačima $i$ promotorima ljudskih akcija" (Dulčić: 2014:89), potiču debate koje isključuju figurativan utjecaj na vanjskopolitičke odluke američke, ali i savezničkih administracija, istovremeno smatrajući da je njihova dužnost sprečavanje ratnih sukoba, obrana etničkih i vjerskih manjina za ugrožene skupine u svijetu. Tom prilikom značajno se koriste spinovanjem $^{8}$ kao jednim od glavnih instrumenata medijske manipulacije, kroz razne tehnike provođenja (selektivno iznošenje činjenica, davanje pomno smišljenih izjava, kazivanje u pogrešnom krugu, uporaba eufemizama, prikrivanje loših vijesti, ističući i gurajući u prvi plan populizam itd.).

Timothy Bewes, kada je riječ o prethodnome, napominje da je , spin sam po sebi paradoksalan koncept, pa ipak izgrađuje našu političku realnost kao nijedan drugi. Spinovanje se mora posmatrati u smislu... objektivizacije, koja označava postepenu nadmoć objektivne (vanjske) kulture nad subjektivnom (unutrašnjom) kulturom, drugim riječima, postepenu nadmoć brige za prividom nad stvarnošću“. 9

Općenito promatrajući, smatra se da je svaka politika, odnosno svaka vlast nastojala ili nastoji manipulirati informacijama, prikriti loše, a istaknuti njima

\footnotetext{
8 Prof. B. Jovanović ističe da je ,spinovanje svesno obmanjivanje javnosti nekom lažnom pričom da bi se njome postigao željeni efekat, da se pokrene javno mnjenje i pridobiju politički partneri kao saveznici za ostvarivanje određenih političkih ciljeva“. Nadalje, smatra da „objavljivanje karikature proroka (poslanika) Muhameda kao teroriste je pokušaj da se muslimani i islamska vera demonizuju i označe kao opasnost. To, naravno, treba sagledati u kontekstu montiranja izveštaja o nuklearnom naoružavanju Irana, što je istovetan scenario primenjen na Iraku. Ova karikatura treba da pridobije najširu javnost za onu opciju koja je najmanje poželjna, a to je vojna intervencija. Kada su milioni muslimana počeli da iskazuju svoje nezadovoljsto objavljivanjem karikatura, Danci, koji su je objavili, branili su se pravom na slobodno izražavanje mišljenja. Međutim, ta sloboda nije neograničena, ona se završava tamo gde se drugi osete ugroženim, gde osete opasnost i povredu svojih osećanja“.

Vidjeti više na: http://www.mc.rs/kad-spin-doktor-zavrti-pricu.50.html?eventId=23947 (pristupljeno dana 30. siječnja 2016. godine).

9 Timothy Bewes (2014.), Krug spinovanja: Istina i privid u politici, vidjeti više na: http://www. media.ba/bs/magazin-etika/krug-spinovanja-istina-i-privid-u-politici (pristupljeno dana 1. veljače 2016. godine).
} 
dobre strane, optužujući druge za svoje neuspjehe, istovremeno glorificirajući svoje minimalne uspjehe, šireći zadani pravac i djelovanje.

Međutim, može se primijetiti da se u tom političkom pravcu, odnosno u sprezi vlasti i politike, djeluje isključivo selektivno, što se ogleda na primjeru i odnosu prema američkim saveznicima i onima koji to nisu. U prenesenom kontekstu, američki saveznici prvenstveno (Izrael, Saudijska Arabija, Velika Britanija, Francuska i dr.) teško će se naći na udaru američke vanjske politike, dok tamo gdje postoji interesna sfera, odnosno prepreka njihovim interesima, situacija je potpuno drugačija. Ovdje bismo se na trenutak vratili na početak ovog podnaslova, kako bismo s pravom produbili konstataciju da ovaj i ovakav oblik selektivizma ima sve odlike imperijalizma i teško možemo povjerovati da će se spomenuta svjetska sila odreći toga prava na ekspanzionizam sve dok bude u mogućnosti da ga provodi.

S druge strane imamo Rusiju, nasljednicu Sovjetskog Saveza, pokretačku snagu u nekadašnjem Varšavskom paktu rođenog kao protuteža Atlantskom, NATOpaktu koji i danas postoji u promijenjenom i znatno proširenom sastavu. Općenito govoreći, takmičenje za prevlast po mnogim pitanjima (vojnim, nuklearnim, ekonomskim i dr.) Sjedinjenih Američkih Država i njezinih saveznika s jedne strane, Rusije i njezinih strateških partnera s druge strane, u mnogome imaju za posljedicu stvaranje nesigurnosti prvenstveno u bliskoistočnim zemljama, u Europi, ali i u ostatku svijeta.

U tom kontekstu, u proteklih petnaest godina nadmetanja među velikim silama, kao i obnovljene nestabilnosti na Bliskom istoku, uključujući u taj front i Arapsko proljeće ${ }^{10}$ koje je počelo u Tunisu krajem 2010. godine, kroz uspon terorističke grupe ISIL-ISIS-DAIŠ, ${ }^{11}$ zatim ratove preko posrednika između sunita i šiita, ${ }^{12}$ proizvodeći time neopisivu ljudsku patnju - nesigurnost kao instrument postizanja rezultata odnosno zadovoljenja ciljeva, najblaže rečeno, bila je i još uvijek jest veoma intenzivna, napredujuća i destabilizirajuća.

Kada je riječ o terorističkom djelovanju, odnosno o suvremenom terorizmu kao takvom, a prema riječima Jeana Baudrillarda (2007:10-12), isti je nastao kao reakcija na globalizaciju... ističući da se tu radi o „teroru protiv terora“, dalje naglašavajući da se "terorizam nalazi u samom srcu kulture koja se bori protiv njega“.

10 Vidjeti više na: http://balkans.aljazeera.net/tema/arapsko-proljece (pristupljeno dana 22. ožujka 2016. godine).

11 Vidjeti više na: https://sh.wikipedia.org/wiki/Islamska_Dr\%C5\%BEava_Irak_i_Levant (pristupljeno dana 22. ožujka 2016. godine).

12 Vidjeti više na: http://hr.sott.net/article/751-Objasnjenje-rata-u-Siriji-za-sve-koji-zele-znati (pristupljeno dana 23. ožujka 2016.godine). 


\section{SUVREMENI TERORIZAM S ASPEKTA BOSANSKOHERCEGOVAČKE ZBILJE (KAZNENOPROCESNI OSVRT)}

Globalizacija je najznačajniji društveni proces u historiji ljudskog društva koji obuhvaća sve aspekte društvenog života, uključujući ekonomiju, kulturu, obrazovanje, jezik, ideologiju i vrijednosti (Marković, 2009:18).

Globalizacija je zasigurno modificirala društvo u kojem živimo i donijela sa sobom negativnosti koje su evidentne. Drugim riječima, produbila je nejednakosti i stvorila ogromni jaz u društvu, a njezini negativni rezultati snažan su poticaj fundamentalizmu, agresivnom nacionalizmu, ksenofobiji itd., koji svijet dijele na različite civilizacije (Milardović, 2004:90).

Kada govorimo o Bosni i Hercegovini, državi u tranziciji s izuzetno specifičnim političkim uređenjem, sigurnosna zbilja prošlosti, ali i sadašnjosti, nije na nivou koju bi željeli svi građani koji žive u njoj. Naime, sve što se dogodilo u proteklim godinama na tom području implicitno nam ukazuje da suvremeni terorizam obuhvaća široku skalu brutalnih, beskompromisnih akcija, i raznovrsnih protivnika, ali se i dalje ovom pitanju pristupa separatno.

U ovom dijelu dat ćemo kratak pregled izvršenih terorističkih akata u BiH, iz kaznenoprocesnog kuta, i ujedno se osvrnuti na tretiranje terorizma i radikalizma s ciljem identificiranja nedostataka $u$ formalnoj reakciji na terorizam.

Šire promatrajući, Bosna i Hercegovina nije imuna na pojave terorizma uopcee, ${ }^{13}$ bili smo svjedoci i još uvijek smo, velikog broja terorističkih akata posljednjih godina u Bosni i Hercegovini čime se javlja posebna potreba za ukazivanjem na rađanje, širenje i napredovanje suvremenog terorizma, al i i svjetske komercijalizacije straha. Postoji opravdana bojazan da je BiH pogodna platforma za razvijanje i uobličavanje ideje o suvremenom terorizmu zbog geostrateške pozicije i ne tako sjajne ekonomsko-političke situacije. Nameće se pitanje kakve su to geopolitičke

13 Grabovica, A. (2015.), „Terorizam i prevencija terorizma u Bosni i Hercegovini“, Znakovi vremena, godina XVIII., broj 67, str. 139, Sarajevo: „Korijeni i uzroci pojave terorističke prijetnje u Bosni i Hercegovini najčešće se vežu za period agresije na Bosnu i Hercegovinu od 1991. do 1995. godine... Područje Balkana, a posebno Bosne i Hercegovine, pogodno je tlo za propagiranje i sukobljavanje interesa velikih igrača na međunarodnoj sceni. Korijeni i uzroci pojave terorizma u Bosni i Hercegovini počinje neposredno i u toku agresije na Republiku Bosnu i Hercegovinu, kada obavještajne službe iz Srbije i sl. vrše tajne operacije - terorističke činove. Odred „El-Mudžahedin“ sveukupno je sačinjavalo 1774 osobe (ICTY, Spisak pripadnika odreda El-Mudžahedin VJ 5689, Zenica, 26. 02. 1996.) od čega su broj od 252 osobe (ICTY, Spisak pripadnika odreda El-Mudžahedin stranog porijekla, 07. 05. 1995.) činili ljudi stranog porijekla. Znatan broj tih ljudi napustio je Bosnu i Hercegovinu i otišao negdje na ratišta u Afganistanu, Iraku, Čečeniji, Sudanu i na neke druge prostore na kojima se vode ratni sukobi. U poratnim godinama u tranzitu su došli drugi, koji su se iz raznoraznih razloga našli u Bosni i Hercegovini i tu kraće ili duže boravili. Uz ljude koji su osposobljeni i moguće spremni za izvođenje terorističkih napada, u Bosni i Hercegovini se održala i ideologija koju su oni donijeli i širili.“ 
i geostrateške promjene nastupile a da nužno zahtijevaju preoblikovanje svijesti o budućim dešavanjima. U širem kontekstu proizvodnje i širenja nesigurnosti kroz oblike suvremenog terorizma, provođenih od strane zapadnih zemalja, koje za krajnji cilj imaju destabilizaciju geostrateškog područja u sigurnosnom, ali i u svim drugim aspektima, kamuflirana je šira zadaća njihove opstojnosti u takvim izmijenjenim okolnostima. Zapadnim silama prvenstveno je potrebna dominantna strateška pozicija u obavještajnom sektoru i njihovoj djelatnosti, odnosno kvalitetna protuteža istim takvim službama koje dolaze s Istoka, a kojih na prostoru BiH ima nemali broj. Pored toga, kroz održavanje pat-pozicije (ne)sigurnosti, uzimajući u obzir trusno tlo u smislu podložnosti eskalacije sukoba, potrebno im je, dugoročno promatrajući, kontinuirano prisustvo (vojno, političko, diplomatsko, ekonomsko), ali tu je i potreba za prirodnim resursima, tržištem roba, potencijalnom radnom snagom, prostorom za ulaganje kapitala, proširenim izvorima energije itd. Te zadaće su naprosto dobro prikrivene ili maskirane i implicitno govore o složenosti te problematike.

U tom pravcu Radovanović (2015.) ističe da se vrlo jednostavno može obrazložiti zbog čega je destabilizacija Balkana tako nužna interesima Sjedinjenih Američkih Država. Autor navodi da Sjedinjene Američke Države nisu sposobne same poraziti ogromni pojas od Tunisa do Irana, ali i dalje. Za takav cilj nužna im je pomoć europskih saveznika, no, pitanje je kako animirati Europsku uniju, točnije pojedine vojno moćne članice, za ovaj geostrateški plan. Jednostavno, destabilizacija cjelokupnog Balkana od strane radikalnih islamista u Europi može proizvesti realan ili manipulativni strah dovoljan za angažiranje protiv te nove opasnosti. ${ }^{14}$ Dakako, pretpostavka je da bi se to angažiranje ogledalo u svim aspektima za koje zapadne administracije smatraju da su od ključnih interesa za njih same.

Činjenice kazuju da je za kratko vrijeme moguće provesti regrutaciju i poslati na ratišta simpatizere iz pojedinih vjerskih zajednica, posebno uključujući metodu prozelitizma, slijedeći ideje radikalizma ${ }^{15}$ svake vrste, pod prezentiranim im

14 Radovanović, B. (2015.), Zalud ruka pomirenja i muzika, eskalacija srpsko-bošnjačkih odnosa slijedi, vidjeti više na: http://borislavradovanovic.blogspot.ba/2015_07_01_archive.html (pristupljeno dana 6. lipnja 2016.).

15 Nepstad, Sharon (2004: 298), „Religion, Violence and Peacemaking“, Journal for the Scientific Study of Religion, a prema: Juergensmeyer, M. (2000.), Terror in the Mind of God, ističe da vjerski ekstremisti imaju sljedeće karakteristike: 1) trenutno stanje religije doživljavaju kao oslabljenu verziju autentične vjere. Oni su poklonici vjere koja je zahtjevnija i traži žrtvu; 2) odbijaju kompromis sa sekularnim institucijama, kritizirajući slabe religije zbog konformističkog odnosa prema vladajućem trendu u kulturi. Na taj način radikalni islamisti pozivaju na jači otpor zapadnjačkom utjecaju, jevrejski doseljenici osuđuju izraelske političare koji su spremni da pregovaraju oko okupiranih teritorija, pojedini hrišćani se otvoreno i nasiljem protive dozvoljenom abortusu. Ovakvo protivljenje zakonima doživljavaju kao opravdano, obzirom da se građanske odgovornosti smatraju drugorazrednim u odnosu na religiju i sa njom povezane obaveze; 3 ) religijski ekstremisti odbacuju podjelu na privatno i javno, gdje se vjera smatra za nešto privatno, što treba da bude izvan politike. Neki od njih se čak nadaju da će doprinijeti uništavanju sekularne države, što bi dovelo do konačnog zavođenja teokratije. 
izgovorom o odsutnosti vjerskih prava i sloboda, o ispravljanju nepravde, stradanju i patnji naroda, ali i boljem životu u zemljama gdje žive braća po vjeri, odnosno pripadnici iste religijske skupine. U tom pravcu, Azinović, Jusić (2015:49) sugeriraju kako se pojedinci i skupine radikaliziraju u vezi s percepcijom patnje i stradalništva šire, globalne zajednice, koju doživljavaju kao svoju.

Općenito, kod većine prevladava percepcija da je napadnut islam i da je njihova dužnost braniti ga, jer poruke koje dolaze do njih od strane ideoloških autoriteta, ali i s ratišta, precizno su formulirane kao ohrabrenje i poziv za obranu globalne zajednice i uspješan obračun s njezinim protivnicima.

Ovdje je bitno pojasniti da se islam kao religija ne bavi terorizmom kao takvim, ali pojedine osobe koje se predstavljaju kao pripadnici te religije, nažalost se bave, isto kao što se tijekom 60-ih, 70-ih i 80-ih godina prošlog stoljeća ni druge religije nisu bavile terorizmom u tom kontekstu, ali jesu pojedinci koji su se izjašnjavali da pripadaju, ili su pripadali, tim religijskim skupinama.

Posljednje informacije govore da pored priključivanja terorističkim organizacijama na ratom zahvaćena područja, također imamo i odlaske na strana ratišta iz $\mathrm{BiH}$, ali i iz susjednih zemalja od strane pojedinaca iz drugih nacionalnih korpusa, odnosno pojedinih pripadnika drugih vjerskih skupina u cilju priključivanja različitim vojnim i paravojnim formacijama. Tako su npr. pojedinci iz hrvatskog korpusa odlazili u borbu na ukrajinsko ratište na strani ukrajinske vojske, dok su pripadnici srpskog naroda kao dobrovoljci odlazili na ista ratišta, u ruske vojne paraformacije koje su ratovale na tom području. Pored navedenog, trenutno su registrirani pojedinci, odnosno srpske dobrovoljne jedinice na sirijskom ratištu, koje su priključene službenoj sirijskoj vojsci kao pomoćna snaga ruskim vojnim zadaćama, tj. interesnim sferama. ${ }^{16}$

Prvi čin okarakteriziran kao teroristički u BiH od njezine samostalnosti desio se u Mostaru 1997. godine u obliku napada na Policijsku upravu, kada su za isti procesuirani i osuđeni A. Z. H., A. A. H. i N. A. H. na ukupno 23 godine zatvora. U Sarajevu je 1999. godine ubijen doministar unutarnjih poslova Federacije Bosne i Hercegovine, međutim taj teroristički akt, odnosno sudski postupak još uvijek nije okončan, iako su pokrenute mnoge aktivnosti vezane za slučaj.

Pored Konjica, u selu Kostajnica, 2002. godine izvršen je teroristički akt na nacionalnoj osnovi, gdje je, nakon procesuiranja slučaja, optuženi M. T. osuđen na 35 godina zatvorske kazne.

Ispred policijske stanice u Bugojnu 2010. godine desio se teroristički akt za koji su optuženi H. Č. i A. H. Sudsku presudu od 45 godina zatvora dobio je H. Č.,

16 Vidjeti više na: http://thebosniatimes.ba/clanak/4483 (pristupljeno dana 06. lipnja 2016. godine). 
međutim ta presuda mu je ukinuta 2013. godine, a u drugostupanjskom postupku isti je osuđen na 35 godina, dok je A. H. priznao učešće u ovom gnusnom činu i sudski epilog iznosio je 14 godina zatvora.

U Zvorniku 2015. godine dogodio se napad na policijsku stanicu i tom prilikom je napadač N. I. ubijen.

Godine 2008. u tržnom centru u Vitezu (FIS Vitez) izvršen je teroristički akt, kada je eksplozivna naprava ubila jednu, a više njih ranila. Za teroristički akt osuđeni su S. Đ. na 9 godina i A. I. na 2 godine zatvorske kazne.

Pored navedenih terorističkih akata, u 2012. godini pokrenut je sudski postupak protiv optuženog M. J., E. F. i M. A. za organiziranje terorističke grupe iz člana 202d. stav 2. Kaznenog zakona Bosne i Hercegovine, u vezi s kaznenim djelom terorizma iz člana 201. stav 1. u vezi sa stavom 5. tačka a) i d) KZ BiH. Optuženi su, kao pripadnici organizirane terorističke grupe, tijekom 2011. godine odlučili da zajedničkim djelovanjem, napadom na zgradu ambasade Sjedinjenih Američkih Država u Bosni i Hercegovini izvrše teroristički čin. M. J. je pravosnažnom odlukom Sudskog vijeća BiH osuđen na 15 godina zatvora, dok su E. F. i M. A. oslobođeni optužbe za pomaganje zbog nedostatka dokaza. ${ }^{17}$ Sredinom 2014. godine E. F. je poginuo u Iraku, počinivši samoubilački napad, gdje je otišao zbog priključenja ISIL-u/ISIS-u.

Optužnica iz 2006. godine navodi da su se B. M., C. A. i ostali teretili za kazneno djelo terorizma iz člana 201. stav 1. u vezi sa stavom 4. tačka f) Kaznenog zakona Bosne i Hercegovine, odnosno u namjeri da na teritoriju $\mathrm{BiH}$ ili neke druge europske zemlje izvrše teroristički akt. ${ }^{18}$ Optužnica dalje navodi da je cilj takvog terorističkog napada bio prisiljavanje vlasti BiH ili vlade druge države da povuku svoje snage iz Iraka i Afganistana. Osim navedenoga, optuženi su se teretili i za kazneno djelo sprečavanja službene osobe u vršenju službene radnje iz člana 359. stav 1. Kaznenog zakona Federacije BiH, a ostali za kazneno djelo nedozvoljenog držanja oružja ili eksplozivnih materija iz člana 371. stav 2. ovog Zakona. Prvooptuženi je dobio jedinstvenu kaznu zatvora od 8 godina i četiri mjeseca, a drugooptuženi 6 godina i četiri mjeseca.

U 2009. godini, Sud BiH je podigao optužnicu protiv R. R., H. A. i V. E. za kaznena djela: terorizam, udruživanje radi činjenja kaznenih djela i neovlašteni promet oružjem i vojnom opremom, te proizvodima dvojne namjene i udruživanje radi činjenja kaznenih djela, a 2011. godine i donio prvostepenu presudu koja

17 Sudska praksa: predmet broj: S1 2 K 00772312 K. Vidjeti više na: http://www.sudbih.gov.ba/?op cija $=$ predmeti\&id=997\&jezik=b (pristupljeno 02. svibnja 2016. godine).

18 Sudska praksa: predmet broj: X-KŽ-06/190. Vidjeti više na: http://www.sudbih.gov.ba/?opcija=pr edmeti\&id=24\&jezik=b (pristupljeno 02. svibnja 2016. godine). 
je kasnije i potvrđena u drugostepenom postupku i prvooptuženog osudio na jedinstvenu kaznu zatvora u trajanju od 4 godine i šest mjeseci, ${ }^{19}$ a drugooptužene na 3 godine i četiri mjeseca, odnosno 3 godine i četiri mjeseca.

Poseban problem, kako ističu autori Azinović i Jusić, predstavljaju povratnici sa ratišta u Bosnu i Hercegovinu, ističući da je ipak za pretpostaviti da se većina boraca povratnika neće u budućnosti angažirati u aktima nasilja u Bosni i Hercegovini, ali i bez toga veterani iz Sirije i Iraka, sa stečenim ugledom autentičnih boraca za vrijednosti s kojima se identificiraju, u svojim bi lokalnim zajednicama mogli postati nekom vrstom društvenih uzora, osobito za mlade s margina, neprilagođene, otuđene i dezorijentirane. Oni su već svakako ranjiviji i najizloženiji procesu radikalizacije i vrbovanja koji prethode odlascima na strana ratišta (Azinović, Jusić, 2015: 54).

Pored iznesenih navoda, pretpostavlja se da je za jedan dio ovih osoba bitan faktor bio i socijalno-ekonomska situacija koja je takoreći ubrzala donošenje odluke o odlasku na strano ratište, bez obzira na mogućnost posljedica, kako na samom ratištu, tako i eventualnog povratka u Bosnu i Hercegovinu. Činjenice pokazuju da jedan dio ovih osoba zaista dolazi iz marginaliziranih slojeva našeg društva.

U tom pravcu, govoreći prije svega o suzbijanju, prevenciji i borbi protiv ovakvih pojava u Bosni i Hercegovini, ističemo da u Bosni i Hercegovini postoji specifičan državni ustoj, a samim tim i karakterističan oblik policijskih struktura. ${ }^{20}$ Općenito gledajući, na području BiH postoji decentralizirani karakter policijskih struktura u kojima djeluju 22 policijske agencije, što uveliko ima otežavajuću zadaću i okolnosti za jedinstvenu i konsolidiranu evidenciju svih osoba koje odlaze, nalaze se i vraćaju sa stranih ratišta.

Analizom sadržaja utvrđeno je da postoje izuzetno bitni faktori koji se tiču dopuna Kaznenog zakona Bosne i Hercegovine, ${ }^{21}$ između ostalog i u glavi XVI Kaznena djela protiv integriteta Bosne i Hercegovine.

Posebnosti dopune Kaznenog zakona ogledaju se u novom članu 162b (Protuzakonito formiranje i pridruživanje stranim paravojnim ili parapolicijskim formacijama) kojim se sankcioniraju osobe koje organiziraju, rukovode, provode obuku, opremaju ili mobiliziraju pojedince ili skupine ljudi da se pridruže

19 Sudska praksa: predmet broj: S1 2 K 00334210 K (veza broj: X-K-09/670-1). Vidjeti više na: http://www.sudbih.gov.ba/?opcija=predmeti\&id=254\&jezik=b (pristupljeno 03. svibnja 2016. godine).

20 Pregled stanja u oblasti policije BiH (2013.), Centar za sigurnosne studije BiH, Sarajevo - vidjeti više na: http://css.ba/wp-content/uploads/2011/06/images_docs2_pregled\%20stanja\%20policije $\% 20$ u\%20bih.pdf (pristupljeno dana 28. travnja 2016. godine).

21 Temeljem člana IV.4.a, Ustava Bosne i Hercegovine, Parlamentarna skupština Bosne i Hercegovine na 67. sjednici Zastupničkog doma, održanoj 28. svibnja 2014. godine, i na 38. sjednici Doma naroda, održanoj 6. lipnja 2014. godine, usvojila je Zakon o dopuni Kaznenog zakona Bosne i Hercegovine (Službeni glasnik Bosne i Hercegovine br. 47/14). 
stranoj vojnoj, paravojnoj ili parapolicijskoj formaciji koja djeluje izvan Bosne i Hercegovine. Pored navedenoga, sankcionirano je i pridruživanje takvim formacijama, uključujući i poticanje na izvršenje ovog kaznenog djela, zatim nabavku sredstava, vrbovanje i druge radnje kojima se stvaraju uvjeti za direktno počinjenje ovog kaznenog djela.

Prva optužnica protiv osoba za koje se tvrdi da su počinile kazneno djelo iz člana 162 b podignuta je u proljeće 2015. godine, a sudska presuda izrečena je krajem iste godine. Tužiteljstvo Bosne i Hercegovine optužene H. E. i ostale je teretilo da su tijekom 2013. i 2014. godine, kao pripadnici selefijske ${ }^{22}$ zajednice organizirane na području Bosne i Hercegovine, izvan službenih institucija Islamske zajednice, u nekoliko gradova, radi propagiranja i širenja islamskog radikalizma u Bosni i Hercegovini i regionu, svjesno sa pozicije vjerskih autoriteta javno podsticale druge da se priključe terorističkim organizacijama, konkretno ISIL-u/ISIS-u, tzV. Islamskoj državi na području Sirije i Iraka, a koja je odlukom Vijeća sigurnosti UN-a broj SC/11019 od 30. svibnja 2013. godine proglašena terorističkom organizacijom. ${ }^{23}$ Sud $\mathrm{BiH}$ je prvooptuženog osudio na kaznu zatvora od 3 godine i 6 mjeseci, dok su ostali osuđeni na jednu i pol, odnosno na godinu dana zatvora.

Do početka 2015. godine, točnije do primjene člana 162b Kaznenog zakona Bosne i Hercegovine, Tužiteljstvo BiH u sudskim je procesima protiv osoba za koje se smatralo da su ključni u procesu vrbovanja i poticanja na odlaske na strana ratišta, konkretiziralo optužnice na temelju ranijih dopuna Kaznenog zakona BiH, odnosno članova 202a (Javno poticanje na terorističke aktivnosti), zatim 202b (Vrbovanje radi terorističkih aktivnosti) i 202d (Organiziranje terorističke skupine). Tako je u studenome 2015. godine, H. B. nepravomoćno osuđen na 7 godina zatvorske kazne, zbog planiranja i vrbovanja, organiziranja terorističkih aktivnosti.

Za N. I. se smatra da je nasljednik nepravomoćno osuđenog H. B., i trenutno je izvan domašaja sigurnosnih snaga Bosne i Hercegovine, odnosno pretpostavlja se da je posljednje dvije godine proveo na sirijskom ratištu, iako se u 2010. godini nalazio pod istragom po prijedlogu Tužilaštva Bosne i Hercegovine, za kaznena djela organiziranog kriminala i u vezi s kaznenim djelima napada na ustavni poredak i ugrožavanja teritorijalne cjeline kao i kaznenim djelima iz Kaznenog zakona Federacije Bosne i Hercegovine: izazivanje narodnosne, rasne i vjerske

22 Salafiti (prethodnici) pripadnici su čiste islamske sunitske sekte koja se pojavila u 19. stoljeću u Egiptu, kao intelektualni pokret na sveučilištu al-Azhar. Budući da su isključivo prihvaćali autoritet Kur'ana i Sune, s vremenom su se, u vjerovanju, približili Vahabitima. Inzistiraju na potpunom $\mathrm{i}$ nedvosmislenom povratku načina življenja u skladu s islamskim naukom. Vidjeti više: Ćosić-Dragan, Daniel (2008.), „Islam P \& O - Pitanja i odgovori“", u: National Security and the Future 1-2 (9), str. 89-121 (str. 113). godine).

23 Vidjeti više na: http://www.sudbih.gov.ba/?id=4174\&jezik=b (pristupljeno 02. svibnja 2016. 
mržnje, razdora i netrpeljivosti i nedozvoljeno držanje oružja ili eksplozivnih materija, ali mu je tada Sud Bosne i Hercegovine ukinuo pritvor i izrekao određene mjere zabrane. ${ }^{24}$

Bosna i Hercegovina je od 2006. godine do danas imala ukupno tri usvojene Strategije za prevenciju i borbu protiv terorizma (2006.-2010.; 2010.-2015. i 2015.2020.). Posljednja je usvojena u srpnju 2015. godine, ${ }^{25}$ a ista u svojoj viziji ima za zadatak ostvarivanje ciljeva i to:

- U represivnom smislu - što prije svega podrazumijeva prikupljanje i pravovremenu analizu i dalje ustupanje svih raspoloživih obavještajnih podataka, provođenje sistemskih, potpunih i koordiniranih istraga svih pojava nasilnog ekstremizma i terorizma, pojačanu razmjenu informacija na međunarodnom nivou, primjenu najboljih istražnih praksi i drugih procedura i smjernica. Razvitak sistema ranog upozorenja.

- U preventivnom smislu akcent se stavlja na otklanjanje svih uzroka koji mogu voditi nasilnom ekstremizmu i terorizmu, saradnji s nevladinim sektorom, uključujući vjerske zajednice, te ostvarenju podrške i aktivne uključenosti najšire društvene zajednice, posebno mladih, u procese suzbijanja govora mržnje, zločina iz mržnje i terorizma. Poticati sve aktivnosti u društvu koje su usmjerene na razvoj demokratskog društva u kojem je osigurana potpuna vladavina prava, te aktivnosti koje su usmjerene na promoviranje dijaloga i tolerancije.

I pored dosadašnjih Strategija, primjetno je da se upravo u vremenskom periodu kada su postojale navedene strategije, desilo i najviše terorističkih napada u $\mathrm{BiH}$, konkretnije u 2010. godini napad na policijsku stanicu u Bugojnu, u 2012. godini napad na Američko veleposlanstvo u Sarajevu, zatim u 2015. godini napad na policijsku postaju u Zvorniku, a u 2015. godini napad na pripadnike Oružanih snaga Bosne i Hercegovine u Rajlovcu - Sarajevo itd.

Moglo bi se na osnovi toga zaključiti da postoje specifični i teško premostivi problemi kako u samim policijskim strukturama koje se izravno suprotstavljaju

24 Vidjeti više na: http://www.sudbih.gov.ba/?id=1550\&jezik=b (pristupljeno 02. svibnja 2016. godine)

25 STRATEGIJA BOSNE I HERCEGOVINE ZA PREVENCIJU I BORBU PROTIV TERORIZMA 2015. - 2020. Usvojena na 14. sjednici Vijeća ministara BiH dana 08. srpnja 2015. godine. Strategija Bosne i Hercegovine za prevenciju i borbu protiv terorizma donosi se u cilju suzbijanja terorizma i s terorizmom povezanih pojava u Bosni i Hercegovini, te ispunjenja obaveza koje je Bosna i Hercegovina preuzela na međunarodnom planu, posebno onih koje proizlaze iz Sporazuma o stabilizaciji i pridruživanju Europskoj uniji. Strategija predstavlja izraz kontinuiteta i spremnosti Bosne i Hercegovine za dalje jačanje nacionalnih kapaciteta u oblastima prevencije i borbe protiv terorizma, ali i suzbijanja, svih drugih, s terorizmom povezanih pojava. Ovim dokumentom postavljena načela, vizija i misija, te utvrđeni ciljevi u suglasnosti su s dokumentima Ujedinjenih naroda, NATO-a i Europske unije. 
ovakvim i sličnim sigurnosnim izazovima, tako i u cjelokupnom sigurnosnom sektoru, a, priznat ćemo, i u političkom nejedinstvu i nestabilnosti na svim nivoima. Samim time, pravni mehanizmi za borbu protiv terorizma koji postoje u BiH ne mogu u punom kapacitetu dati željene rezultate u toj borbi, zbog čestog preklapanja nadležnosti sigurnosnih institucija, ostavljajući time prostor za propuste. Pored toga, općenito promatrano sa stajališta sociološke i društvene svijesti, značajan problem predstavlja fokusiranje ove problematike kroz prizmu etničkog modaliteta i kulturne raznolikosti, ne uzimajući u obzir razloge i faktore koji su doprinijeli tome da se pojedinci, suštinski govoreći, okrenu terorizmu i odluče na korak ka priključenju terorističkim organizacijama. Na kraju, kada je riječ o prethodno navedenim terorističkim djelima, pretpostavka je da izrečene kazne nisu imale nikakav preventivni rehabilitacijski aspekt, a to je od ključne važnosti. Bez preventivnog rehabilitacijskog aspekta osuđenici su samo spriječeni provoditi terorističke akte u fizičkom smislu, dok istovremeno postoji realna mogućnost dodatne radikalizacije u jedinicama gdje služe zatvorsku kaznu, ali i širenja iste na one koji do sada nisu bili radikalizirani. ${ }^{26}$ Odnosno, drugačije rečeno, ako se osuđenici po ovim parametrima ne uključe u program deradikalizacije, drugi osuđenici koji i nemaju dodirnih točaka s terorizmom mogu biti radikalizirani. Bez adekvatnog programa rehabilitacije, zatvorske kazne nemaju efekta u smislu preveniranja takvih budućih pojava, a s druge strane mogu imati i kontraefekt u smislu eskalacije radikalizacije. U Bosni i Hercegovini potencijalni faktor rizika za radikalizaciju je u prvobitnom obliku sekundarni element u kontekstu socioekonomskih i društvenih (ne)prilika, odnosa u obitelji i dr., a zatim u drugoj fazi i kao nadogradnja (produbljivanje) na prvobitni oblik (npr. radikalizacija na izdržavanju zatvorske kazne).

Općenito govoreći, kod ljudi osuđenih po kaznenim djelima terorizma to se uklapa u njihovu viziju svijeta gdje dolaze do zaključka da su progonjeni od društva, želeći da im to društvo nanese nepravdu ili zlo, dok su oni istovremeno pokazali svoju hrabrost i spremnost da se žrtvuju time što su otišli u zatvor. Oni u svojim očima ili očima istomišljenika postaju heroji i to će svrsishodno koristiti po izlasku iz zatvora u takvom ili sličnom miljeu kroz autoritativno djelovanje, odnosno radeći na stvaranju vlastitog pedigrea, kao što imamo primjer kod određenih kriminalnih organizacija.

26 Kao primjer navest ćemo životnu ispovijest Mevlida Jašarevića koji je osuđen za teroristički napad na Veleposlanstvo SAD-a u BiH, odnosno intervju u dokumentarnom filmu „Napadanje“, u čijem sadržaju postoji detaljna ilustracija početka njegove radikalizacije u zatvoru u okolici Beča (gdje je prije bio osuđen na kaznu zatvora zbog pljačke banke u Austriji) i nastavka radikaliziranja po izlasku iz zatvora: https:// www.youtube.com/watch?v=W0q2kWb99wQ (pristupljeno dana 01. srpnja 2016. godine). 


\section{ZAKLJUČAK}

Protiv suvremenog terorizma borba se vodi zakonitim sredstvima, ali se on time zasigurno ne može dugoročno riješiti, odnosno eliminirati. Poznato je da proizvodnja svakog oblika ekstremizma raste kada su ljudska prava narušena ili ugrožena, kada se politički prostor sužava ili pretvara u gordijski čvor, kada se ignoriraju zahtjevi svih za društvenu inkluziju, kada se značajan broj ljudi, naročito mladih, ostavlja bez perspektive i pozitivne vizije. Nakon sagledavanja takve situacije, pojedine osobe ne vide drugo i drugačije rješenje osim u samoadaptiranju i nastojanju kultivacije u smjeru otuđenosti i radikalizacije.

Za pretpostaviti je da važan, a vjerojatno i presudni element o kojemu ovisi ekspanzija terorizma jest reakcija društva u punom kapacitetu. Općenito promatrajući, konstatacija da terorizam nije moguće iskorijeniti do samog kraja, jer kao i svaki korov, s vremenom će ponovno izniknuti, treba shvatiti potpuno ozbiljno i realno, permanentno radeći na lokalnim nivoima u njegovu suzbijanju da bi se u konačnici uspješno kontrolirao od strane sigurnosnih institucija na državnom nivou. Na tom polju se ne smije kasniti. Kada je riječ o globalnom pogledu na ovaj problem, sasvim realno i bez lažnog skepticizma moguće je očekivati konstantu u održanju jednog od najvećih sigurnosnih problema, jer kao što smo i elaborirali u samom radu, mnogi svjetski faktori utječu na nastanak, rađanje i proizvodnju suvremenog terorizma. U tom smislu, bosanskohercegovačko nesigurno trusno tlo pogoduje raznim ideološkim aktivnostima i importima zapadnih sila, kao i sila koje dolaze s Istoka, s idejom dugoročnog zadržavanja na tom prostoru, ne libeći se, čini se, da ga tako uvjetno rečeno drže pod patronatom, na određeni način uzrokujući i produbljujući time ranije navedene negativnosti.

Srž rađanja i proizvodnje suvremenog terorizma implicitno ne dolazi iz pojedinačnih lokalnih i državnih okvira gdje ubrajamo i BiH, već se ta pošast širi iz laboratorija stranih svjetskih sila (Zapada i Istoka) i njihove vanjske politike, potpomognute prije svega obavještajnom mašinerijom, gdje za posljedicu imamo žrtve širom Europe kroz terorističke akte, dok se na Bliskom istoku s druge strane svakodnevno uvećava broj žrtava prouzročenih destabilizirajućom i ekspanzionističkom politikom globalnih svjetskih centara.

U prilog toj i takvoj politici govore i činjenice iz 2001. godine kada je šest bosanskohercegovačkih naturaliziranih državljana (alžirska skupina), osumnjičenih za planiranje napada na ambasadu Sjedinjenih Američkih Država u Sarajevu, uhićeno od pripadnika Ministarstva unutarnjih poslova Federacije Bosne i Hercegovine. 
Naime, protiv uhićenika nisu bile podignute optužnice za kazneno djelo terorizma, međutim nedugo zatim oduzeto im je bosanskohercegovačko državljanstvo. Vrhovni sud Federacije BiH u siječnju 2002. godine donosi rješenje o ukidanju pritvora za šestoricu osumnjičenika jer nisu postojali relevantni dokazi o podizanju optužnice. Samo dvanaest sati nakon puštanja iz pritvora, pod vidnim međunarodnim pritiskom, tzv. alžirska skupina ilegalno je predana obavještajnim službenicima Sjedinjenih Američkih Država i deportirana na Guantanamo Bay na Kubi, u američku vojnu bazu. Vlada Sjedinjenih Američkih Država navodno je ponudila Vijeću ministara Bosne i Hercegovine uvjerljive indicije da pripadnici tzv. alžirske skupine mogu osigurati relevantne informacije za međunarodnu borbu protiv terorizma. Tamo su držani u pritvoru godinama bez podizanja optužnice, a poslije dugogodišnjeg boravka na Kubi, 2009. godine, Sjedinjene Američke Države oslobodile su petoricu zbog nedostatka dokaza, a 2010. godine, nakon revizije slučajeva, Sud za apelacije Sjedinjenih Američkih Država oslobodio je i šestu osobu iz te skupine. Zaključak je bio da posljednji oslobođeni B. B. nije član Al-Qaide i da bi trebao biti oslobođen. U prosincu 2013. godine, usprkos njegovu negodovanju i strahu da će biti meta terorističkih organizacija, isti je deportiran u Alžir.

Navedeni primjer eklatantno pokazuje da je vizija vođene politike zapravo iznad svega ostalog, odnosno to je primarni cilj državnih organa jedne zemlje, moglo bi se reći čak i iznad svih prava, iako se jedno od osnovnih načela prirodnog prava (ius naturale) očituje kroz vladavinu prava i u pravnoj sigurnosti svih građana.

Iznad glava nam posljednjih godina visi pitanje da li su i koliko bosanskohercegovačke institucije efikasne u prevenciji i suzbijanju potencijalnih terorističkih prijetnji, a autentičan odgovor mogla bi nam dati situacija na terenu.

Bosna i Hercegovina ima osjetljiv i nezavidan geostrateški položaj u Europi, nalazeći se istovremeno na čvorištu balkanskih ruta organiziranog kriminala. Kao što smo i iznijeli u samom radu, otežavajuću okolnost u suzbijanju i borbi protiv terorizma, kao pošasti modernog vremena, imamo i u trenutnoj ekonomskopolitičkoj situaciji u Bosni i Hercegovini, ali i u specifičnosti sigurnosnog sustava države, koja je također jedan od elemenata usporavanja u kontekstu antiterorističke borbe.

Globalizacijski interesi velikih svjetskih sila (ekonomski, politički i dr.) sve više imaju prednost nad zaštitom i očuvanjem temeljnih ljudskih prava i ostalih vrijednosti zaštićenih međunarodnim pravom. Ekonomska moć $\mathrm{i}$ kontrola prirodnih resursa ključni su elementi za stvaranje globalnog svjetskog poretka sa snažnim zasebnim interesima, dok je briga za humane ciljeve i vrijednosti, koje proklamiraju svi međunarodni dokumenti o ljudskim pravima, jednostavno marginalizirana. 
Takvo djelovanje stvara hranjivo tlo za dalju ekspanziju modernog terorizma kao takvog i za provođenje terorističkih napada u svijetu, ostavljajući nam istovremeno neizvjesnu budućnost.

Suzbijajući nesavladiv rast globalne nejednakosti koja za posljedicu ima osiguravanje regruta, odnosno vrbovanje osoba za pridruživanje terorističkim organizacijama i izvršavanje terorističkih akata, saznanja iz travnja 2016. godine kazuju da su i vjerske institucije/zajednice Bosne i Hercegovine poduzele određene mjere u suzbijanju terorizma i širenju terorističkih aktivnosti.

Naime, Islamska zajednica Bosne i Hercegovine uputila je poziv na dijalog i postizanje dogovora s pojedincima i skupinama, pripadnicima islama, koji djeluju izvan institucija Zajednice, na načelima koja nisu unutar islamske tradicije i ustavnih odredbi Zajednice na teritoriju Bosne i Hercegovine. Epilog nam govori da su od 38 takvih skupina, predstavnici 14 skupina potpisali Protokol i prihvatili uključenje u Zajednicu, a preostale skupine su iskazale interes za rješavanje pitanja razlika i pitanja izvaninstitucionalnog djelovanja. Pored potpisanog sporazuma, zaključak je da Zajednica treba razmotriti mogućnosti razvijanja programa i ostvarivanja projekata socijalizacije, odnosno posebne resocijalizacije za osobe kojima je to potrebno, kako bi se uhvatili u koštac s ovom problematikom i odlučnije krenuli ka cilju prevencije i suzbijanja suvremenog terorizma u bosanskohercegovačkom društvu, konkretnije sprečavanja vrbovanja osoba za terorističke aktivnosti koje se dovode u vezu s vjerskim zajednicama.

Na kraju, može se sasvim sigurno zaključiti da je neophodno tražiti rješenja u dogovorima, točnije u diplomaciji, koja je spomenuta na početku rada kao zaboravljena disciplina, jer povratak istoj kao vještini pregovaranja u miru, vještini rješavanja konfliktnih situacija, vještini razumijevanja i tolerancije, može biti nužno, ali i presudno sredstvo, kako za umirivanje svjetskih kriza, tako i kriza na lokalnim, odnosno državnim nivoima.

\section{LITERATURA}

- Azinović, V., Jusić, M. (2015.), Zov rata u Siriji i bosanskohercegovački kontingent stranih boraca, Istraživački projekat - Atlantska inicijativa, Sarajevo.

- Baudrillard, Jean (2007.)., Duh terorizma, Arhipelag, Beograd.

- Beck, U. (2003.), Što je globalizacija? Zablude globalizma - odgovori na globalizaciju, Biblioteka Novi poredak, Vizura, Zagreb.

- Bržežinski, Zbigniew (2001.), Velika šahovska tabla, CID, Podgorica.

- Bušljeta-Tonković, A. (2014.), „Suvremeni terorizam - globalna sigurnosna 
prijetnja i/ili oblik antiglobalizacijskoga djelovanja“, pregledni članak, Mostariensia, 18, 1-2.

- Cooper, H. H. A. (2001.), „Terrorism: The Problem of Definition Revisited“, American Behavioral Scientist 44.

- Ć́osić, D. D., (2008.), „Islam P \& O - Pitanja i odgovori“, u: National Security and the Future 1-2 (9).

- Dulčić, D. (2014.), „Masovni mediji i postmoderno društvo“, Media, culture and public relations, 5, 1, 87-97, Hrvatsko komunikološko društvo, Zagreb.

- Džamić, D. (2004.), Cia iznutra, Knjiga komerc, Beograd.

- Đorić, M. (2011.), Globalizacija i politički ektremizam, II deo: Međunarodna politika i međunarodni odnosi, Godišnjak broj 5, jun 2011: 417-418, Fakultet političkih nauka, Beograd.

- Gaćinović, R. (2010.), Terorizam u političkoj i pravnoj teoriji, Evro-Giunti, Beograd.

- Grabovica, A. (2015.), ,Terorizam i prevencija terorizma u Bosni i Hercegovini“", Znakovi vremena, godina XVIII., broj 67, Sarajevo.

- Harmon, C. (2002.), Terorizam danas, Goldenmarketing, Zagreb.

- Hobsbaum, E. (2008.), Globalizacija, demokratija i terorizam, Arhipelag, Beograd.

- Kalinić, Pavle (2003.), Teror i terorizam, Jesenski i Turk, Zagreb.

- $\quad$ Mandelbaum, M. (2006.), The Case for Goliath, Filip Višnjić, Beograd.

- Marković, D. Ž., (2009.), „Planetarna ekonomska kriza i regioni“, publikacija Regionalni razvoj i demografski tokovi zemalja Jugoistočne Evrope, Ekonomski fakultet u Nišu, 17-25, Niš.

- $\quad$ Milardović, A. (2004.), Pod globalnim šeširom - društva i države u tranziciji $i$ globalizaciji, Centar za politološka istraživanja, Zagreb.

- Nepstad, S. (2004.), „Religion, Violence and Peacemaking“, Journal for the Scientific Study of Religion, 43:3.

- Odluka Vijeća sigurnosti UN-a o proglašenju terorističke organizacije broj SC/11019.

- $\quad$ Orehovec, Z., Stipetić, D. (2011.), Terorizam i obrana od terorizma, Veleučilište Velika Gorica, Velika Gorica.

- Pratt, D. (2006.), „Terrorism and Religious Fundamentalism: Prospects for a Predictive Paradigm“, Marburg Journal of Religion, Volume 11, No. 1.

- Ranković, M. (2005.), „Suvremeni/ globalni terorizam: sociološki pristup“, pregledni naučni članak, Beograd. 
Mr. sc. Almir Pustahija: Generiranje suvremenog terorizma kroz prizmu negativnih konotacija... Zbornik radova Pravnog fakulteta u Splitu, god. 53, 4/2016., str. 1095.-1118.

- Steger, M. B. (2005.), Globalizacija, Šahinpašić, Sarajevo.

- Stiglitz, J. E. (2009.), Uspjeh globalizacije: Novi koraci do pravednog svijeta, Algoritam, Zagreb.

- Strategija Bosne i Hercegovine za prevenciju i borbu protiv terorizma 2015. 2020. od 08. 07. 2015. Godine.

- Turek, F. (1999.), Globalizacija i globalna sigurnost, Hrvatska udruga za međunarodne studije, Varaždin.

- Vujaklija M. (1980.), Leksikon stranih reči i izraza, Prosveta, Beograd.

\section{Internetski izvori:}

- Admir Crvčanin, „Napadanje“ (2015.), dokumentarni film, dostupno na: https://www.youtube.com/watch?v=W0q2kWb99wQ ( pristupljeno dana 01. srpnja 2016. godine).

- Borislav Radovanović (2015.), Zalud ruka pomirenja i muzika, eskalacija srpsko-bošnjačkih odnosa slijedi, vidjeti više na: http://borislavradovanovic. blogspot.ba/2015_07_01_archive.html (pristupljeno dana 06. lipnja 2016. godine).

- Centar za sigurnosne studije BiH, Sarajevo (2013.), Pregled stanja u oblasti policije BiH, dostupno na: http://css.ba/wp-content/uploads/2011/06/images_ docs2_pregled\%20stanja\%20policije\%20u\%20bih.pdf (pristupljeno dana 28. travnja 2016. godine).

- Članak u novinama, dostupno na : http://thebosniatimes.ba/clanak/4483 (pristupljeno dana 06. lipnja 2016. godine).

- Članak u novinama, dostupno na: http://balkans.aljazeera.net/tema/arapskoproljece ( pristupljeno dana 22. ožujka 2016. godine).

- Članak u novinama, dostupno na: http://hr.sott.net/article/751-Objasnjenje-ratau-Siriji-za-sve-koji-zele-znati (pristupljeno dana 23. ožujka 2016. godine).

- Članak, elektronički izvor, dostupno na: https://sh.wikipedia.org/wiki/Islamska_ Dr\%C5\%BEava_Irak_i_Levant ( pristupljeno dana 22. ožujka 2016. godine).

- Članak/intervju, Prof. dr. Jovanović Bojan, dostupno na: http://www.mc.rs/kadspin-doktor-zavrti-pricu.50.html? eventId=23947 (pristupljeno 30. siječnja 2016. godine).

- Objavljeno izlaganje sa skupa: FALIŠ-Festival ljevice i alternative, Dizdarević, Z. (2015.), Šibenik, dostupno na: http://kontrapress.com/ clanak.php?rub=Politika\&url=Idemo-u-susret-fasisoidnom-korporativnomimperijalizmu (Pristupljeno: 26. studenoga 2015.). 
Mr. sc. Almir Pustahija: Generiranje suvremenog terorizma kroz prizmu negativnih konotacija... Zbornik radova Pravnog fakulteta u Splitu, god. 53, 4/2016., str. 1095.-1118.

- Timothy Bewes (2014.), Krug spinovanja: Istina i privid u politici, dostupno na: http://www.media.ba/bs/magazin-etika/krug-spinovanja-istina-i-privid-upolitici (pristupljeno dana 1. veljače 2016. godine).

\section{Sudski slučajevi:}

- dostupno na $:$ http://www.sudbih.gov.ba/?id=1550\&jezik=b (pristupljeno 02 . svibnja 2016. godine)

- dostupno na: http://www.sudbih.gov.ba/?id=4174\&jezik=b (pristupljeno 02 . svibnja 2016. godine)

- dostupno na: http://www.sudbih.gov.ba/?opcija=predmeti\&id=24\&jezik=b (pristupljeno 02. svibnja 2016. godine)

- dostupno na: http://www.sudbih.gov.ba/?opcija=predmeti\&id=254\&jezik=b ( pristupljeno 03. svibnja 2016. godine)

- dostupno na: http://www.sudbih.gov.ba/?opcija=predmeti\&id=997\&jezik=b (pristupljeno 02. svibnja 2016. godine)

\section{Sudska praksa:}

- Presuda Suda Bosne i Hercegovine u Sarajevu, protiv optuženih B. M. i C. A., predmet broj: X-KŽ-06/190, od 21. 05. 2007. godine.

- Presuda Suda Bosne i Hercegovine u Sarajevu, protiv optuženih M. J., E. F. i M. A., predmet broj: S1 2 K 00772312 K, od 06. 12. 2012. godine.

- Presuda Suda Bosne i Hercegovine u Sarajevu, protiv optuženih R. R., H. A. i V. E, predmet broj: S1 2 K $00334210 \mathrm{~K}$ (veza broj: X-K-09/670-1), od 10. 11. 2011. godine.

\section{Zakonski i podzakonski akti:}

- Kazneni zakon Bosne i Hercegovine (Službeni glasnik Bosne i Hercegovine br. 3/03).

- Kazneni zakon Federacije BiH (Službene novine FBiH, br. 43/98, 2/99, 15/99, 29/00 i 59/02).Zakon o dopuni Kaznenog zakona Bosne i Hercegovine (Službeni glasnik Bosne i Hercegovine br. 47/14). 


\section{THE PRODUCTION OF CONTEMPORARY TERRORISM THROUGH THE PRISM OF THE NEGATIVE CONNOTATIONS OF GLOBALIZATION - BOSNIA AND HERCEGOVINA CASE}

The author analyzes contemporary terrorism, delving deeply into different dimensions of causation and production of modern terrorism, and looking critically at the negative connotations of globalization and global processes in the world as key factors that greatly contribute to creating insecurity, with its accompanying consequences. The research approach applied in this paper may explain the essence of modern terrorism to and facilitate the rejection of widely-accepted opinions based on incomplete and distorted information that result in the production of fear of terrorism. Also, the paper analyzes the terrorist acts that took place in Bosnia and Herzegovina since its independence until today from the criminal procedural and security point of view, pointing to the possibility of increased insecurity and the treath of terrorism, which is reflected in the specific ways in society, but also overviewing the specific aspects of the overall security sector of Bosnia and Herzegovina, and its struggle to prevent and suppress internal, interstate and transnational terrorism. In its conclusion, the paper refers to the fact that in addition to state institutions that are involved in the activities of prevention and fight against terrorism, there are other important actors, such as religious institutions/ communities in Bosnia and Herzegovina, that are actively involved in the aforementioned activities.

Key words: Modern terrorism, causation, globalization, criminal-procedural aspect 